\title{
A Case of Dyskeratosis Congenita Associated with Hypothyroidism and Hypogonadism
}

\author{
NILUFER OZDEMIR KUTBAY ${ }^{1}$, ZEHRA ERDEMIR ${ }^{2}$, BANU SARER YUREKLI ${ }^{1}$, EMIN KARACA ${ }^{3}$, MEHMET ERDOGAN $^{1}$, SEVKI \\ CETINKALP1, GULSEN KANDILOGLU ${ }^{4}$, GOKHAN OZGEN ${ }^{1}$, FERDA OZKINAY ${ }^{3}$ FUSUN SAYGILI $^{1}$ \\ EGE UNIVERSITY FACULTY OF MEDICINE, ENDOCRINOLGY AND METABOLISM DEPARTMENT, IZMIR \\ EGE UNIVERSITY FACULTY OF MEDICINE, INTERNAL MEDICINE DEPARTMENT, IZMIR ${ }^{2}$ \\ EGE UNIVERSITY FACULTY OF MEDICINE, MEDICAL GENETICS DEPARTMENT, IZMIR ${ }^{3}$ \\ EGE UNIVERSITY FACULTY OF MEDICINE, PATHOLOGY DEPARTMENT, IZMIR ${ }^{4}$
}

\section{Objectives:}

\section{Methods:}

Dyskeratosis congenita is a rare multisystemic disease characterized with atrophy on skin, pigmentation, nail dystrophy, leukoplakia in mucous membrane, bone marrow failure and tendency to malignancy. We present a rare case of dyskeratosis congenita associated with hypothyroidism and hypogonadism.

A 30-year-old male patient was referred to Endocrinology Department with the findings of micropenis and atrophic testicules. His parents had cousin marriage. Physical examination results: BP: 130/80mmHg, Height: $172 \mathrm{~cm}$, Weight: $83 \mathrm{~kg}$, BMI: 28kg/m². There were hypopigmented skin lesions in the whole body. The skin was dry and the nails were dystrophic (Figure1). His axillary and pubic hair was normal but facial hair was scarce. He had alopecia in 1/3 of outer eyebrow (Omnibus sign) and saddle nose (Figure 2A,B). Micropenis and testicles were found to be atrophic. The Laboratory findings: WBC: $3140 / \mathrm{mm}^{3}$, neutrophil: $1740 / \mathrm{mm}^{3}$, $\mathrm{Hb}: 12.5 \mathrm{gr} / \mathrm{dL}$, plt: $187000 / \mathrm{mm}^{3}$, Free testosterone: $1.4 \mathrm{pg} / \mathrm{mL}$, Total Testosterone: $0.70 \mathrm{ng} / \mathrm{mL} \mathrm{FSH}: 77.28 \mathrm{mlU}, \mathrm{LH}: 15.38 \mathrm{mlU}, \mathrm{E} 2:<20 \mathrm{pg} / \mathrm{ml}$, Prolactin:6.77 ng/mL, DHEAS:222.1 mcg/dL, freeT3:3.35 pg/ml, freeT4:0.98 ng/ dl, TSH: 10.88 $\mathrm{mIU} / \mathrm{L}$, anti TG: $203 \mathrm{IU} / \mathrm{ml}, \mathrm{ACTH}: 24.1 \mathrm{pg} / \mathrm{mL}$, cortisol:13.34 mcg/dl. Hypergonadotropic hypogonadism was suspected as testosterone was low and FSH and LH were high. Hyperkeratosis keratoderma was found in skin biopsy. In the biopsy of lymph node from right cervical, we found disseminated histiocytic proliferation that changes the normal appearance of lymph node and granulomas that are characterized with rare giant cell formation and that don't include necrosis.

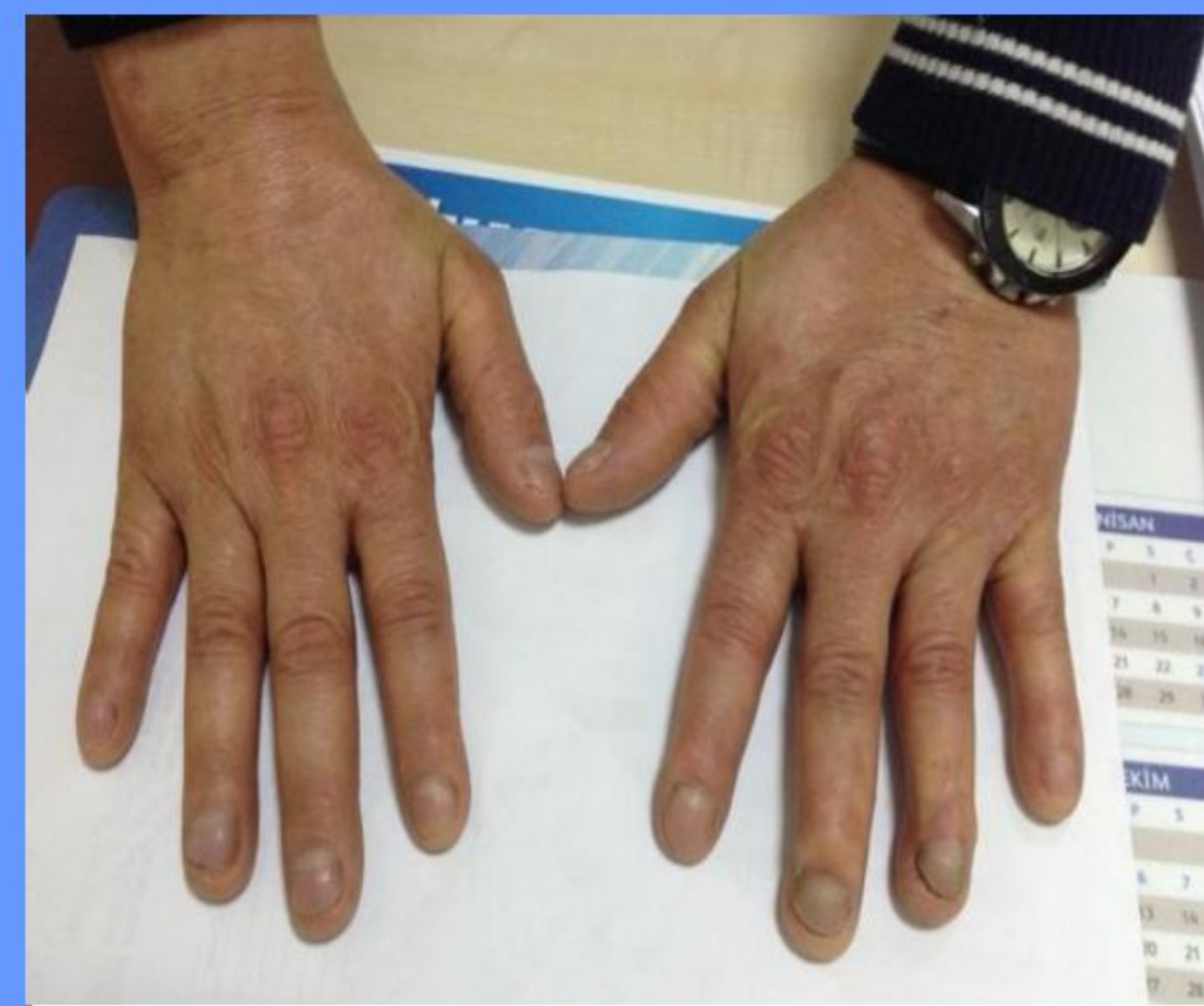

Figure 1. Dystrophic nail image of our case with dyskeratosis congenita
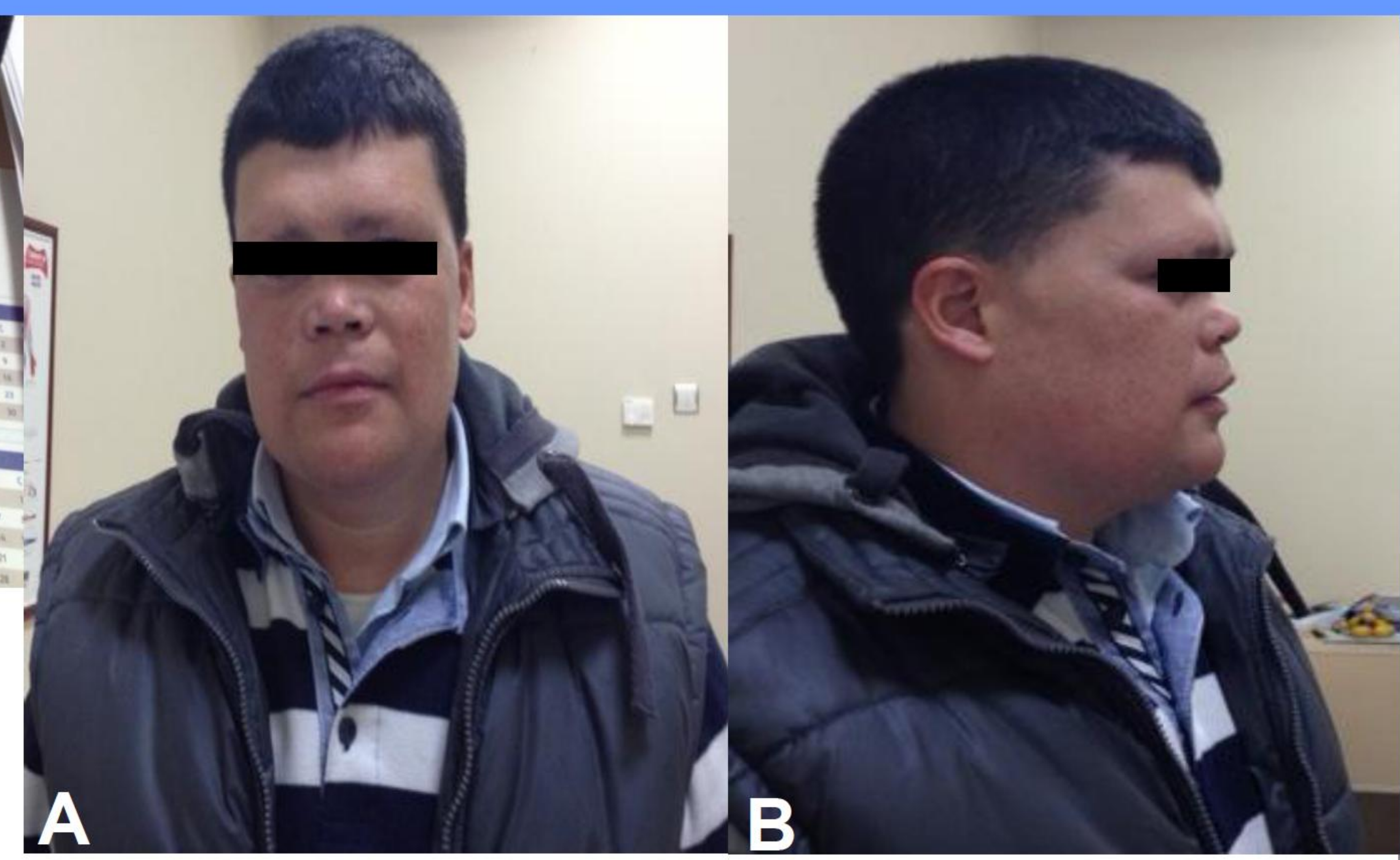

Figure 2.

A: Image of our case with dyskeratosis congenita (alopecia in 1/3 of outer eyebrow)

B: Image of our case with dyskeratosis congenita (saddle nose)

Conclusions:

Dyskeratosis congenita is a rare disease showing $X$-linked recessive inheritance along with autosomal dominant and recessive forms. Although the pathogenesis of the disease is still unknown, DKC1 gene localized to Xq28 is thought to be responsible for the X-linked dyskeratosis congenita. Our patient is still genetically studied. In this syndrome, the association of hypothyroidism and hypogonadism should be kept in mind. 